\title{
THE IMPACT OF ONLINE LEARNING ON THE LEARNING MOTIVATION OF PRIMARY SCHOOL STUDENTS
}

\author{
Rizka Alfarimba ${ }^{1}$, Sekar Dwi Ardianti ${ }^{2}$, Khamdun $^{3}$ \\ ${ }^{1,2,3}$ Universitas Muria Kudus, Kudus, Indonesia
}

\begin{tabular}{|c|c|}
\hline Article Info & ABSTRACT \\
\hline Article history: & \multirow{8}{*}{$\begin{array}{l}\text { This study aims to describe the learning motivation of grade } 5 \text { students in Gondo- } \\
\text { sari village as a result of the implementation of online learning during the covid-19 } \\
\text { pandemic. This research uses the descriptive qualitative method. The objects of this } \\
\text { study are } 6 \text { students of grade with the categorization of rank, their parents educational } \\
\text { background, and their parent's occupation and } 1 \text { classroom teacher who teach online } \\
\text { in grade } 5 \text { of SD } 7 \text { Gondosari village. With observation, semi-structured interviews, } \\
\text { and documentation as tools for data collection. The validity test of this study used } \\
\text { triangulation of online learning has on impact on students learning motivation with } \\
\text { indicators of learning motivation, namely perseverance in facing tasks, resilience in } \\
\text { facing difficulties, interest in various problems, working independently, and factors } \\
\text { from the learning environment. This indicator can measure the extent to which the } \\
\text { learning motivation of grade } 5 \text { students of SD } 7 \text { Gondosari. }\end{array}$} \\
\hline Received: 02-02-2021 & \\
\hline Revised: 20-02-2021 & \\
\hline Published: $10-05-2021$ & \\
\hline Keywords: & \\
\hline Learning motivation & \\
\hline Online learning & \\
\hline Elementary Students & \\
\hline
\end{tabular}

This is an open access article under the CC BY-SA license.

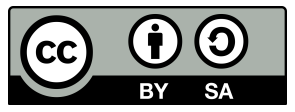

\section{Corresponding Author:}

Rizka Alfarimba,

Elementary Education Study Program, Faculty of Teacher Training and Education, Universitas Muria Kudus, J1. Lkr. Utara, Kayuapu Kulon, Gondangmanis, Kec. Bae, Kabupaten Kudus, Jawa Tengah, Indonesia.

Email: rizkaalfa09@gmail.com

\section{INTRODUCTION}

At the end of the month in 2019 in China, to be precise, the city of Wuhan was hit by an outbreak of the Corona Virus Disease (Covid-19). The virus that attacks the respiratory and immune systems in humans was initially considered just like the common cold, in fact the virus can develop more rapidly so that it can cause a more severe condition that attacks important organs in humans. Not only does it quickly spread in the body affected by the virus, the Covid-19 virus also easily spreads to other people. Circumstances outside the prediction of the Covid -19 virus have spread throughout the world, including Indonesia. In Indonesia, everyday, the number of people infected with the Covid-19 virus is increasing because this situation causes Indonesia to enter a national emergency.

Various attempts were made to break the chain of spreading the Covid-19 virus, namely by limiting activities that would have an impact on the spread of the virus. Because of the restrictions on these activities that have urged various sectors, one of which is the education sector. Education is an important sector. The field of education which includes teaching and learning activities is also affected by this pandemic where the process of teaching and learning activities is more carried out online (Erfan \& Maulyda, 2020). Education is an important aspect for humans (Suprihatin, 2015). Therefore, learning activities must continue. Learning is a long process to achieve better results (Meidawati, Sobron, \& Bayu, 2019). One of the steps taken is an official circular by 
the Ministry of Education and Culture No36962/MPK.A/HK/2020 about the enactment of online learning and working from home in order to prevent Covid-19 transmission. The existence of this circular is the beginning of the termination of learning in the classroom into online learning. Online learning is the delivery of virtual learning with the help of applications as a tool to convey learning (Syarifudin, 2020). The policy applies to all levels of education. The success of online learning is influenced by several factors, namely, the technology used, the characteristics of the teacher, and the characteristics of the students themselves (Pangondian, Santosa, \& Nugroho, 2019).

Implementing online learning is not easy because of course there are obstacles and shortcomings in its application (Rahman, 2007). Although the time for children to study at home is longer, the results are not optimal because children tend to be bored. The habit of students studying together with their friends in class and being explained directly by the teacher makes one of the obstacles for children adapting to online learning. The large amount of time at home and the lack of facilities and infrastructure that support children's learning activities at home are also obstacles to the implementation of online learning. Because there are many obstacles encountered in implementing online learning which ultimately have an impact on learning motivation. Djamarah (2015) explains that motivation is a change in the energy that is in a person to do something. The purpose of learning to be successful is related to the motivation of students (Meidawati et al., 2019). Therefore, student motivation is needed.

The existence of this online learning has a considerable impact on children's motivation in learning. The motivation to learn at the age of elementary school children is influenced by several factors, namely internal and external factors. The main external factor comes from the family. Motivation to learn is the main factor affecting student learning outcomes. Online learning programs require families, especially parents, to assist teachers in guiding students according to learning procedures during online learning. Internal factors are felt from within the students themselves are influenced by the different abilities of each student in receiving the material provided by the teacher. Nashar (2004) stated that the learning motivation that students have in each learning activity plays a very important role in increasing student achievement in certain subjects.

\section{RESEARCH METHOD}

The method used in this research is descriptive qualitative. This qualitative research was conducted by collecting data that researchers got from observations. The data were obtained in the form of observation notes, interview notes, field documentation, photographs and other supporters. In this study the researchers focused on the impact of online learning on $5^{\text {th }}$ grade student learning motivation. The instrument used in this study was an interview instrument for students and teachers. In addition to the interview and research observation instruments, note-taking sheets were also used to summarize the things that were found in the implementation of the research. Interview and observation instruments are used by researchers because with these two instruments, the researcher will face with sources who are expected to obtain more accurate information (Windiyani, 2012).

The focus of this research took place in the village of Gondosari, to be precise, on $5^{\text {th }}$ grade students at SD 7 Gondosari, Kudus district. Where at this location has informants in accordance with the categorization used for data collection. This study focused on the impact of online learning on the learning motivation of $5^{\text {th }}$ grade students at SD 7 Gondosari during the Covid-19 pandemic.

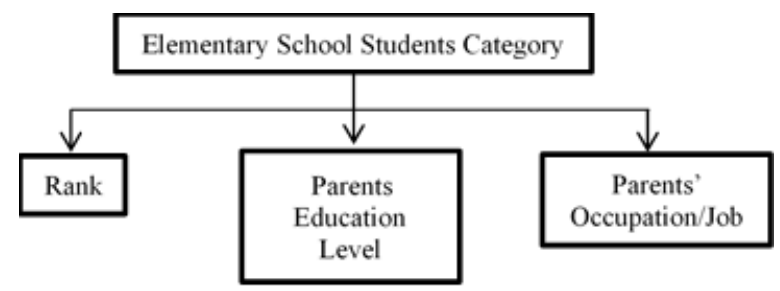

Figure 1. Category of Student Informants

This research data collection technique using observation steps, semi-structured interviews, documentation, and recording research results. The resource persons used in the research were 6 of $5^{\text {th }}$ grade students at SD 7 Gondosari with questions related to the student's learning motivation. Categorization is used to make a comparison of internal and external factors on student learning motivation. The data obtained from the study 
were analyzed and presented in the form of descriptions. Data analysis techniques in this study used an interactive analysis model with steps, data reduction, data presentation, and drawing conclusions.

\section{RESULT AND DISCUSSION}

\subsection{Students' Learning Motivation During Online Learning}

The results of interviews with students related to their learning motivation during online learning are detailed with the results of the interviews in Table 1.

Table 1. Learning Motivation Character for $5^{\text {th }}$ Grade Students on SD 7 Gondosari Children

\begin{tabular}{|c|c|c|c|}
\hline No & Name & Motivation Category & Motivation Character \\
\hline \multirow[t]{5}{*}{1} & NMZL & High & Doing the job seriously \\
\hline & & & Did not hesitate to ask to teacher \\
\hline & & & Loves problem solving questions or essays \\
\hline & & & Happy with the assignment given by the teacher \\
\hline & & & Feel happy if complete assignments successfully \\
\hline \multirow[t]{5}{*}{2} & DKR & High & Doing the job seriously \\
\hline & & & Ask the teacher if there is topic that is not understood \\
\hline & & & Liked essay (discussion) questions \\
\hline & & & Feel satisfied and happy after finishing task optimally \\
\hline & & & Happy with the assignment given by the teacher \\
\hline \multirow[t]{5}{*}{3} & MFR & Moderate & Doing the assignment from the teacher serious enough \\
\hline & & & Feel bored if the topic being taught is not understood \\
\hline & & & Ask for help from relatives or tutors if coming across difficult assignments \\
\hline & & & Prefers multiple choice questions \\
\hline & & & Happy when doing a good job \\
\hline \multirow[t]{4}{*}{4} & MRAR & Moderate & Trying to solve the problem seriously \\
\hline & & & Asking for help with assignments \\
\hline & & & Likes multiple choice questions over problem solving questions \\
\hline & & & Feel relieved when finished working on assignments \\
\hline \multirow[t]{4}{*}{5} & $\mathrm{HPH}$ & Low & Doing the assignment not seriously. \\
\hline & & & Didn't ask the teacher if there is topic that is not understood \\
\hline & & & Not doing assignments independently \\
\hline & & & Dislikes confusing problem \\
\hline \multirow[t]{5}{*}{6} & MAN & Low & Doing the assignment not seriously. \\
\hline & & & Did not want to ask if there's trouble \\
\hline & & & Feel bored when doing assignments by himself \\
\hline & & & Feeling annoyed if asked to do assignments \\
\hline & & & Didn't like essay questions \\
\hline
\end{tabular}

Judging from the data above, for each indicator of learning motivation, it shows different results for each student. Basically, in online learning, it is hoped that there will be reciprocity between teachers and students (Rahma, 2021). Learning motivation itself has indicators of being persistent in facing difficulties, resilient in facing difficulties, showing interest in various problems, and working independently.

The first indicator is being diligent in facing the assignments. The highly motivated students try to be serious in completing the assignments given online. Meanwhile, students who have low motivation tend not to be serious in learning at home. The difference in student persistence can be influenced by the level of students' understanding of the material taught by the teacher. The second indicator is the tenacity in facing the difficulties. The highly motivated students will try to complete the task as good as possible and try to work independently. Meanwhile, students who are tenacious in doing assignments do not really know the material that has not been understood then they will ask the teacher or other people who know better. Third, showing interest in various problems. Motivated students will prefer essay questions because for them solving essay questions will be a challenge and satisfaction if they successfully complete the assignment properly, while students who have low motivation tend to dislike essay questions because they do not like challenges in questions and prefers multiple choice questions. Fourth, working independently. Online learning requires students have more time at home. Students who are highly motivated will try to complete assignments independently, while students who are lowly motivated tend to ask other people for help. The difference in the independence of these students can be influenced by the different self-confidence of each student. Students' independence is usually related to student learning outcomes in class. 
The fifth indicator is boredom with routine tasks. Giving material and assignments online makes students bored with assignments that are routinely given by the teacher. However, some highly motivated students will strive to be enthusiastic in completing online learning. The sixth indicator is being able to defend his opinion. Learning will take place well if there is reciprocity between the teacher and students. Student activeness in learning during online learning is very lacking. Most of the students do not take advantage on learning activities to asking questions and giving answers to the teacher. This is because students admit to being afraid of being wrong in giving their opinion. The seventh indicator is likes to solve the problem. The feelings of each student will certainly be different when they have finished completing the assignment given by the teacher. For students who have high motivation, there will be feelings of pleasure and satisfaction when they have finished completing the assignment, and for students who have low motivation tend to only feel relieved when they have finished working on the assignment from the teacher.

Based on the description above, it can be seen that each student has different motivations in online learning. This difference is caused by different supporting factors for student learning motivation. Rimbarizki (2017) suggests in general the supporting factors for online learning, namely, methods, media and learning places used by children. Classroom teacher as one of the factors that can arouse student learning motivation, prepare online learning properly to achieve learning objectives. The thing that needs to be prepared is the Learning Implementation Plan (RPP). This is supported by Kunandar that the objectives of the lesson plan are (1) improving the results of the learning process; (2) arranging learning systematically to make it easier for teachers to analyze logical and planned learning. In addition, to the preparation of the lesson plan, it creates a new atmosphere by providing innovation in conveying learning to further foster students' enthusiasm for learning, for example by utilizing the surrounding environment (Efendi, 2020). Uno explains that student learning motivation will increase when students experience learning by utilizing a new or different environment than usual. In addition, to use the environment for learning. The teachers can develop innovative learning media as well as create interesting learning is innovative learning (Fakhriyah, Wanabuliandari, \& Ardianti, 2016).

\subsection{The Impact of Online Learning on Student Motivation}

The impact that each student feels during online learning varies. However, what students complain the most is feeling bored during online learning because they spend a lot of time at home. Lack of interaction between students and teachers makes learning delivery difficult and all students say that it is more fun to study together in class. In addition, factors that make students bored and have difficulty learning include facilities at home that do not support online learning, such as signals at home that are good enough. The less conducive home atmosphere is also a factor that obstruct students from learning. Two student informants who have low motivation stated that they are not comfortable studying at home because the home environment is not conducive to learning. The boredom experienced by students makes children less enthusiastic in learning.

The positive side of the impact of online learning for children is the use of technology in the process of teaching and learning activities. Online learning allows teachers to introduce and teach children to use technology as additional insights. Abdulhak explains the use of technology as a tool or media for education, namely as a complement to conveying material; as a source of information and a place to find information; as well as as a learning system (Pujilestari, 2020). However, due to the lack of preparation for the implementation of online learning, the use of online learning activities is not optimal.

The role of parents affects children's learning motivation (Sari, 2017). A supportive children's environment such as parents providing facilities and infrastructure to support children in online learning can foster a sense of enthusiasm and encouragement for children to be serious in learning and doing assignments from the teacher. Grade 5 students at SD 7 Gondosari who have high motivation admit that at home they get maximum guidance and assistance in learning. In addition to assistance in learning, these students also get facilities such as cellphones and networks that are quite good when they are taking online learning and doing assignments from the teacher. The attention of parents who try to take the time to accompany their children in learning will foster a sense of joy for children which in turn will make them more motivated. Online learning makes children learn a lot at home. Learning assistance from families, especially parents, is needed to foster students' motivation. However, not all parents have the free time to accompany their children's learning. Because of this, parents provide facilities such as cellphones for children studying online. From the results of the interview, students who have low motivation, both of them have their own cellphones, but their parents' jobs do not allow them to accompany children to study all the time. Because of that, the cellphones they have tend to be used to play online games so that their study time is quite disturbed because they play games for a long time. 
The role of teachers during online learning in conveying learning also has an impact on student motivation. The teacher act as an aspect that has an interest in delivering material to students. Therefore, the teacher must always have an effort to increase the students' learning motivation, which can be done by giving appreciation with sentences of praise or giving grades. Efforts to increase learning motivation are 1) have goals that must be achieved; 2) nurture student learning motivation; 3) create a pleasant learning atmosphere; 4) use attractive methods; 5) provide appreciation; and 6) competitive competition (Sardiman, 2005).

\section{CONCLUSION}

Based on the results of interviews with students, it was concluded that most of students felt bored in online learning. The boredom felt by students is due to routine assignments by the teacher. Moreover, the students' habit of studying together in the classroom makes they feel bored when studying alone at home. Online learning also has a negative impact on children who have busy parents. Among them, children will tend to be lazy to learn because they are too busy playing games. Therefore, the success of online learning to continue to improve student learning motivation requires good cooperation between parents and class teachers. During unstable conditions, online learning will remain an option to reduce the risk of spreading the Covid-19 virus. Learning innovations by teachers are needed to make it easier for students to understand the topic taught in online learning. For parents, it is better if online learning provides special assistance so that students can study comfortably and make the best use of their time to study.

\section{REFERENCES}

Djamarah, S. B. (2015). Psikologi Belajar. Jakarta: PT. Rineka Cipta.

Efendi, N. (2020). Implementasi Karakter Peduli Lingkungan di Sekolah Dasar Lolong Belanti Padang. Jurnal Komunikasi Pendidikan, 4(2), 62. doi:10.32585/jkp.v4i2.460

Erfan, M., \& Maulyda, M. A. (2020). Pengaruh Game Edukasi Kahoot! Terhadap Penguasaan Konsep Mahasiswa Calon Guru Sekolah Dasar pada Materi Perpindahan Kalor. Jurnal DIDIKA : Wahana Ilmiah Pendidikan Dasar, 6(2), 205-214. Retrieved from http://e-journal.hamzanwadi.ac.id/index.php/didika/ article/view/2694

Fakhriyah, F., Wanabuliandari, S., \& Ardianti, S. D. (2016). Pendampingan Pemanfaatan Sampah Plastik dan Kertas Untuk Media Pembelajaran Inovatif Bagi Guru di SDN 5 Bae, Kudus. Jurnal Pengabdian Pada Masyarakat, 1(1), 48-55. doi:10.30653/002.201611.8

Meidawati, M., Sobron, A., \& Bayu, R. (2019). Persepsi Siswa dalam Studi Pengaruh Daring Learning Terhadap Minat Belajar IPA. SCAFFOLDING: Jurnal Pendidikan Islam dan Multikulturalisme, 1(2), 30-38. doi:10.37680/scaffolding.v1i2.117

Nashar, H. (2004). Peran Motivasi dan Kemampuan Awal dalam Kegiatan Pembelajaran. Jakarta: Delia Press.

Pangondian, A., Santosa, I., \& Nugroho, E. (2019). Faktor- Faktor yang Mempengaruhi Kesuksesan Pembelajaran Daring dalam Revolusi Industri 4.0. In Prosiding seminar nasional teknologi komputer \& sains.

Pujilestari, Y. (2020). Dampak Positif Pembelajaran Online Dalam Sistem Pendidikan Indonesia Pasca Pandemi Covid-19. 'ADALAH: Buletin Hukum dan Keadilan, 4(1), 49-56. doi:10.15408/adalah.v4i1.15394

Rahma, N. S. (2021). Dampak Pembelajaran Daring Terhadap Motivasi Belajar Mahasiswa Selama Pandemi Covid 19. Genta Mulia: Jurnal Ilmiah Pendidikan, 12(1), 113-118.

Rahman, U. (2007). Mengenal Burnout pada Guru. Lentera Pendidikan : Jurnal Ilmu Tarbiyah dan Keguruan, 10(2), 216-227. doi:10.24252/lp.2007v10n2a7

Rimbarizki, R., \& Susilo, H. (2017). Penerapan Pembelajaran Daring Kombinasi dalam Meningkatkan Motivasi Belajar Peserta Didik Paket C Vokasi di Pusat Kegiatan Belajar Masyarakat (PKBM) Pioneer Karanganyar. J PLUS UNESA, 6(2), 1-12.

Sardiman, A. (2005). Interaksi dan Motivasi Belajar Mengajar. Jakarta: PT. Raja Grafindo Persada.

Sari, D. (2017). Peran Orang Tua dalam Memotivasi Belajar Siswa. In Prosiding seminar nasional 20 program pasca sarjana universitas pgri palembang.

Suprihatin, S. (2015). Upaya Guru dalam Meningkatkan Motivasi Belajar Siswa. PROMOSI (Jurnal Pendidikan Ekonomi), 3(1). doi:10.24127/ja.v3i1.144

Syarifudin, A. S. (2020). Impelementasi Pembelajaran Daring untuk Meningkatkan Mutu Pendidikan Sebagai Dampak Diterapkannya Social Distancing. Jurnal Pendidikan Bahasa dan Sastra Indonesia Metalingua, 5(1), 31-34. doi:10.21107/metalingua.v5i1.7072 
Windiyani, T. (2012). Instrumen untuk menjaring data interval. Nominal, ordinal dan data tentang kondisi, keadaan, hal tertentu dan data untuk menjaring variabel kepribadian. Jurnal Pendidikan Dasar, 3(5), 203-208. 